\title{
Menakar Peran Relawan Politik Pasca Kontestasi Presidensial 2014
}

\author{
Bambang Arianto ${ }^{*}$
}

\begin{abstract}
This article explains that the role of post-conflict political volunteers in 2014, who began with the presidential activity mapping and projection of the volunteers. It was to find out the tactical steps taken by the political volunteers, especially in issues of politics and government. This study revealed that volunteers more engaged in social media, then divides typology into a community volunteer and non-volunteer community. From the two typology of volunteers turned out more volunteers who choose passivity rather than active. Passive attituded intended to be a controller of government, while the more active attituded as the guardian of power. This article argues that the role of volunteers in post-conflict digital style presidential politics in 2014 more strengthen the institutionalization of digital activism for political education of the public.
\end{abstract}

\section{Keywords:}

volunteer political; social media; digital activism; the political education of the public.

\begin{abstract}
Abstrak
Artikel ini menjelaskan peran relawan politik pasca kontestasi presidensial 2014 yang dimulai dengan pemetaan aktivitas dan proyeksi para relawan. Hal itu untuk mengetahui langkah taktis yang diambil para relawan politik terutama dalam isu-isu politik dan pemerintahan. Dalam penelitian ini dinyatakan bahwa relawan politik lebih banyak bergerak di ranah media sosial yang kemudian membagi tipologi menjadi relawan komunitas dan relawan non-komunitas. Dari kedua tipologi relawan ini ternyata lebih banyak relawan yang memilih sikap pasif daripada aktif. Sikap pasif ditujukan untuk menjadi pengawas pemerintahan, sedangkan sikap aktif lebih berperan sebagai pengawal kekuasaan. Artikel ini berpendapat bahwa peran relawan dalam langgam politik digital pasca kontestasi presidensial 2014 lebih memperkuat pelembagaan aktivisme digital sebagai wahana pendidikan politik publik.
\end{abstract}

\section{Kata Kunci:}

relawan politik; media sosial; aktivisme digital; pendidikan politik publik.

\section{Pendahuluan}

Gegap gempita perhelatan kontestasi presidensial 2014 yang begitu fenomenal telah berlalu. Tetapi efek dan pengaruhnya hingga saat ini masih terasa, terutama dalam langgam politik digital. Salah satu gejalanya tampak dari terjadinya pembelahan opini

- Mahasiswa Pascasarjana Departemen Politik dan Pemerintahan FISIPOL UGM

Email: bulaksumur4@yahoo.com publik antara pendukung pemerintahan Joko Widodo-Jusuf Kalla (Jokowi-JK) serta pihak yang bersikap oposisi. Gejala ini kemudian melahirkan banyak istilah seperti Jokower (pendukung Jokowi) dengan Jokhaters (pengkritik Jokowi). Akibatnya opini publik dalam langgam politik digital baik di Facebook dan Twitter tampak semakin terbelah. ${ }^{1}$ Meski

\footnotetext{
1 Media sosial dapat menjadi wahana bagi kita untuk memahami realitas politik digital yang kemudian
} 
demikian pembelahan dukungan para netizen tersebut bila ditelisik lebih mendalam masih dalam koridor kegembiraan politik. ${ }^{2}$ Salah satu bentuk kegembiraan politik tergambar dari keberadaan media sosial yang telah melahirkan fenomena aktivisme bagi setiap orang untuk dapat terus mencermati isu-isu politik pemerintahan. Aktivisme tersebut tergambar dari postingan dalam bentuk tulisan, komentar singkat hingga berbagai meme politik. Selain itu gejala aktivisme ini pula yang turut mendorong hadirnya saluran partisipatoris bagi para netizen seperti relawan politik. Istilah relawan (volunteer) dalam historiografi politik dikembangkan semenjak tahun 1755 oleh seorang Perancis M. Fr Voluntaire ketika memberi pelayanan kepada tentara yang sedang berperang. Tugasnya adalah mengabdi secara ikhlas dalam kegiatan altruistik untuk mendorong, memperbaiki, dan meningkatkan kualitas kehidupan di bidang sosial, budaya dan ekonomi. Istilah relawan diambil dari bahasa Jerman "aktivismus" yang muncul pada akhir perang dunia pertama. Istilah ini kemudian digunakan untuk menandai prinsip keterlibatan politik secara aktif oleh kaum intelektual. Bukan hanya pemikiran, tetapi juga usaha untuk membela dan mewujudkan pemikiran tersebut disebut "aktivisme". Aktivismus ini merupakan bagian dari ekspresionisme, yang saat itu memiliki nilai politik sangat kuat.

terbelah menjadi dua yakni kelompok praktis atau (lovers) dan kritis (haters). Dalam konteks ini sikap kritis biasanya ditandai dengan cara berpikir yang lebih partisipatif dan idealis. Artinya baru kali ini dalam sejarah politik Indonesia terjadi pembelahan antara kelompok pendukung dan kelompok kritis. Bahkan sikap kritis seringkali diberi label sebagai pembenci atau haters. Lihat Savirani, Amalinda. (2016). Publik Opinion: Between Haters and Lovers. The Jakarta Post. Edisi 9 Juni.

2 Kegembiraan politik adalah mengembalikan tujuan luhur dan kesucian politik guna memberikan pencerahan dan mengarahkan masyarakat ke hidup yang lebih baik dengan penuh pengorbanan, dan bukan hanya berhenti pada kalkulasi untung-rugi semata. Lihat, Arianto, Bambang. Kampanye Kreatif dalam Kontestasi Presidensial 2014. Jurnal Ilmu Sosial dan Ilmu Politik. Vol. 19 No. 1 Juli 2015.
Biasanya aktivismus dihubungkan dengan Kurt Hiller, pengarah organisasi Neuer Club yang menaungi para penyair ekspresionis awal; maupun Franz Pfemfert, pendiri majalah Die Aktion pada 1911 yang sangat politis. Dalam berbagai pengertian itu, kaum militan maupun aktivismus akhirnya dapat dikatakan sebagai bagian dari relawan (volunteer) (Suryadi, 2014). Akan tetapi kehadiran relawan politik pada kontestasi presidensial 2014 berbeda dengan sejarah awal kelahiran voluntarisme tersebut. Sebab pada kontestasi politik 2014, relawan politik bukan bagian dari anggota partai politik. Para relawan hadir bukan karena daya tarik partai politik, melainkan kepada politik nilai yang melampaui kepentingan partai. Meski demikian, kehadiran relawan politik dapat disinergikan dengan tim sukses pemenangan kampanye sebuah partai politik-karena fungsi mobilisasi yang lebih masif.

Mafhum diketahui fenomena relawan politik pasca reformasi memang telah hadir sejak kontestasi pemilihan kepala daerah DKI Jakarta 2012. Namun, puncaknya geliat relawan politik terjadi pada perhelatan kontestasi presidensial 2014. Itu mengapa, tidak dapat disangkal bila relawan politik disebut sebagai salah satu pilar di balik kemenangan pasangan Joko Widodo Jusuf Kalla (Jokowi-JK). Kerjakerja organisatoris inilah yang kemudian dapat membagi tipologi relawan menjadi dua bagian yakni; relawan komunitas dan relawan non-komunitas. Relawan komunitas, merupakan relawan yang tergabung dalam barisan komunitas yang memiliki ketua atau koordinator seperti layaknya sebuah organisasi. Sedangkan relawan non-komunitas, biasanya bergerak dan bekerja seorang diri (personal) untuk menyebarkan pesan-pesan kampanye Jokowi-JK. Relawan jenis ini seringkali bekerja menurut kemampuan dan kreativitas masingmasing dengan tujuan agar publik dapat semakin mengenal pasangan Jokowi-JK. ${ }^{3}$

${ }^{3}$ Peneliti senior dari Lembaga Ilmu Pengetahuan 
Namun, pasca kontestasi presidensial 2014 peran relawan politik tentulah berubah drastis bila dibandingkan saat kontestasi politik 2014. Sebut saja, kelompok relawan Pro Jokowi (Projo) yang lebih memilih untuk tidak membubarkan diri pasca kontestasi presidensial 2014. Relawan Projo justru lebih memilih mengubah status organisasinya berbentuk organisasi massa (Ormas) Projo yang prosedural. Pembentukan relawan menjadi ormas tersebut karena menganggap bahwa keberadaan relawan politik telah selesai, setelah kontestasi presidensial 2014 berakhir. Pendirian ormas yang bertujuan untuk mengawal pemerintahan Jokowi, merupakan suatu bentuk prinsip relawan Projo yang ingin menyandingkan program pemerintahan Jokowi-JK dengan agenda rakyat. Tujuan lainnya dari relawan Projo yakni berupaya mengontrol pemerintahan Jokowi-JK untuk dapat tetap mengeluarkan kebijakan kebijakan yang dibutuhkan rakyat. ${ }^{4}$ Selain itu perubahan drastis para relawan juga tergambar dari inisiatif relawan politik non-komunitas yang kemudian mendeklarasikan pendirian Partai Indonesia Kerja (PIKA). ${ }^{5}$ Artinya,

Indonesia (LIPI) Siti Zuhro mengatakan, para relawan kini kebanyakan berharap iming-iming balas jasa ketika calon yang mereka dukung berhasil menang dalam pemilu. Pada awalnya, relawan itu dapat meluruskan sistem serta ikut membangun sistem. Tetapi pada akhirnya, relawan tidak berbeda jauh dengan politisi. Artinya, Pilkada hanya dijadikan batu loncatan sebagai pijakan meraih jabatan tertentu. Lihat, kompas.com. (Online). http://megapolitan.kompas.com/ $\mathrm{read} / 2016 / 03 / 31 / 09185951 / . T i d a k . A d a . M a k a n . S i a n g$. Gratis.bagi.Para.Relawan.?utm_source=news\&utm_ medium=bp-kompas\&utm_campaign=related $\&$, diakses 10 Januari 2016.

4 Lihat, hasil penelitian Lembaga Demos, Membaca Dinamika relawan Politik (2015). http://demosindonesia. org/2015/06/membaca-dinamika-relawan-jokowi, diakses 4 Desember 2016

5 Pendukung Presiden Joko Widodo membentuk partai baru bernama Partai Indonesia Kerja (PIKA). Ketua Umum PIKA, Hartoko Adi Oetomo mengatakan partai tersebut di inisiasi oleh para individu yang mendukung sejak menjadi Wali Kota Solo hingga terpilih menjadi Presiden. Lihat Tempo.co.(2015). Pendukung Jokowi Bentuk Partai Indonesia Kerja. (Online). http://m.tempo. deskripsi tersebut semakin menegaskan bahwa langkah taktis yang diambil para relawan semakin mencerminkan dinamika relawan politik sangat dinamis.

Akan tetapi ada pula relawan elektoral non-komunitas yang memilih untuk kembali ke profesi masing-masing seperti, wiraswasta, karyawan, buruh, pegawai negeri sipil dan profesi lainnya. Para relawan non-komunitas ini diakui memang banyak yang memilih sikap pasif ketimbang aktif. Sedangkan yang aktif hingga saat ini masih berselancar di media sosial secara individual sesuai dengan strategi masing-masing. Para relawan non-komunitas ini lebih banyak aktif di media sosial terutama Facebook dan Twitter dalam mempromosikan keberhasilan agenda pemerintahan Jokowi JK. Salah satu alasan mendasar dari para relawan non-komunitas untuk tetap aktif mengkritisi berbagai kebijakan adalah agar pemerintahan Jokowi-JK dapat sejalan dengan kehendak publik, bukan didikte oleh para oligarkis maupun elite partai koalisi pendukung lainnya. ${ }^{6}$

Geliat aktivisme para relawan politik ini kemudian dapat memperkuat pelembagaan aktivisme digital dalam langgam politik Indonesia. Dalam leksikon ilmu politik fenomena aktivisme digital bergerak dengan tujuan utama untuk melakukan penyebaran gagasan, agitasi, advokasi dan catatan-catatan protes dalam medium digital. Artinya, aktivisme digital telah banyak memberikan ruang bagi peningkatan keaktifan publik agar dapat terlibat pada isu-isu politik dan pemerintahan dengan tetap mengedepankan sikap objektif ketika menemui isu-isu kepentingan publik yang berbasis komunikasi deliberatif. Salah satu bentuk aktivisme digital kita temui dengan adanya kemunculan tren dukungan melalui

co/read/news/2016/06/01/ diakses 1 Juni 2016 pukul 23.00 .

6 Wawancara dengan relawan elektoral non-komunitas, Retnowidarti Wulandari melalui Facebook tanggal 22 Mei 2016. 
tagar yang merepresentasikan "ruang publik baru" yang bersifat interaktif.

Alhasil, ruang publik baru inilah yang kemudian dapat mengidentifikasi berbagai karakter para netizen baik di Twitter dan Facebook. Jika mengutip studi yang digelar Public Virtue Indonesia tahun 2012, terdapat tiga jenis karakter para netizen Indonesia yang menggunakan media sosial Facebook. Pertama, "kelompok idios" yakni netizen yang lebih banyak mengangkat masalah kegiatan personal penggunanya; seperti musik, makanan, film, berita tentang artis atau berita keseharian lainnya. Kelompok ini menjadi mayoritas dan menguasai lebih dari 50 persen pengguna, dengan rentang usia sekitar 14-24 tahun. Kedua, "kelompok etnos" yakni netizen yang lebih suka berinteraksi dengan netizen yang dikenal saja. Rata-rata, isu yang diangkat melingkupi masalah dan percakapan dalam dunia offline. Kelompok ini terdiri dari kelompok alumni, peminat hobi, sesama jamaah agama atau kelompok kerja politik. Jumlahnya lebih dari 30 persen pengguna dengan rentang usia sekitar 18-34 tahun. Ketiga, "kelompok demos" adalah netizen yang memang mendedikasikan dirinya untuk melakukan perubahan sosial di dunia nyata dengan menggunakan medium Facebook yang kemudian membuat forum dalam rangka melakukan percakapan isu-isu publik hingga gagasan yang berdampak bagi perubahan sosial. Persentase kelompok ini sekitar 14 persen dengan kisaran umum yang sangat beragam. Rerata setiap individu dari kelompok ini memiliki jalinan pertemanan yang luas dan setiap gagasannya di komentari, disukai atau bahkan dibagikan ulang oleh ratusan hingga ribuan orang.

Dengan beragamnya karakter para netizen membuat penulis ingin menekankan bahwa peran para relawan politik pasca kontestasi presidensial 2014 lebih banyak bergerak diranah media sosial ketimbang bergerak secara offline. Ada beberapa kendala yang menyebabkan mengapa para relawan politik lebih banyak bergerak diranah online. Pertama, tidak ada kesadaran bersama (common enemy) yang dapat menyatukan para relawan politik secara offline. Hal itu disebabkan, pasca elektoral isu-isu politik dan pemerintahan lebih beragam dan sangat sulit untuk diterjemahkan dalam bentuk offline. Kedua, aksi-aksi dalam ranah offline lebih banyak mengeluarkan energi dan waktu ketimbang online. Padahal para relawan non-komunitas juga memiliki banyak pekerjaan di profesi masing-masing. Artinya dengan menggunakan media sosial di rasa lebih efektif dan efisien dalam menyuarakan pendapat serta berpartisipasi dalam isu-isu politik pemerintahan.

Selain kedua kendala tersebut, pemilihan aktif pada media sosial didasari sebagian besar relawan berasal dari kaum muda yang merupakan bagian populasi generasi $\mathrm{Y}$ dan Z. Generasi ini diketahui sangat memiliki ketergantungan yang tinggi terhadap media sosial. Ketergantungan ini kemudian dapat mengonfirmasi studi Andrzej Kaczmarczyk (dalam Heryanto 2016), bahwa interaksi dan ekspresi partisipasi generasi $\mathrm{Y}$ telah menegaskan fenomena demokrasi siber (cyber democracy). Fenomena ini memaparkan empat faktor penting. Pertama, fenomena global dalam mempraktikkan model demokrasi partisipatoris. Dalam konteks ini, politik kerelawanan menguat dan menjadi contoh aktivisme digital terutama lewat media sosial. Para netizen ini tidak lagi hanya sekedar mengonsumsi berita melainkan memproduksi dan menyebarkan gagasan maupun dukungannya. Kedua, komunikasi politik yang berkarakter partisipatoris. Artinya hanya para politisi yang memahami pentingnya transformasi dalam berinteraksi wacana yang bisa bertahan. Sebab gaya kaku, berjarak, high profile, status quo akan disisihkan oleh sosok politisi yang terbuka, populis, berintegritas serta berorientasi perubahan. Ketiga, konflik sering kali dimediasi penggunaan informasi berbasis teknologi komunikasi. Alhasil, 
beragam persoalan akan ditangani dengan cepat. Keempat, transformasi politik yang terhubung ke internet dan memberi akses pada informasi yang sifatnya personal. Contoh aktual adalah inisiatif "Teman Ahok" yang banyak digerakkan anak-anak muda dari kalangan generasi Y. Partisipasi politik generasi Y kini kian menguat dan jadi viral di media sosial, bahkan terhubung dengan aktivitas di dunia nyata. Di dunia maya generasi ini rajin membangun perbincangan, perang wacana, tweet war, merancang publisitas dan kampanye politik untuk mendukung kandidat yang mereka idealkan. Tidak cukup resonansi di media sosial dan media konvensional, generasi ini pun mengumpulkan dukungan warga melalui KTP agar sang kandidat melaju dari jalur perseorangan.?

Gambaran dari menguatnya demokrasi siber tersebut dapat dimanfaatkan untuk mendorong para relawan politik dan netizen lebih aktif mengawal dan mengkritisi setiap isuisu politik pemerintahan. Dengan memberikan kesempatan yang luas bagi para relawan politik dan netizen semakin interaktif sama artinya dengan memperkuat pelembagaan aktivisme digital sebagai wahana pendidikan politik publik. Pendidikan politik dalam konteks ini dapat ditujukan sebagai alternatif untuk memutus beragam informasi yang telah terdistorsi atas kebenaran, pemutarbalikan fakta dan penyelewengan makna dalam langgam politik digital. ${ }^{8}$

\footnotetext{
7 Heryanto, Gun Gun. 4 April 2016. Partisipasi Politik Generasi Digital. Harian Kompas.

8 Dalam kenyataan, tidak sekali dua kali terjadi di komunitas cyberspace justru muncul para haters yang kerap memanfaatkan media sosial dan internet untuk bergunjing, mengkritik, mencaci maki orang lain, tanpa mempertimbangkan dampak sosial psikologis yang dialami korban. Bukan rahasia lagi, media sosial selama ini senantiasa dipenuhi citraan-citraan hiperealitas yang penuh dengan distorsi atas kebenaran, pemutarbalikan fakta dan penyelewengan makna. Ruang publik dalam era masyarakat post industrial sering kali menjadi media bagi siapa pun untuk menyampaikan apa yang menjadi unek-uneknya, tetapi sebagian di antaranya kadang tidak bisa dipertanggungjawabkan. Bagi netizen yang
}

Pendek kata, dengan berakhirnya kontestasi presidensial 2014 telah menandai perubahan rekonfigurasi politik relawan yang kemudian mengajak kita pada dua pertanyaan; Bagaimana peran relawan politik pasca kontestasi presidensial 2014? Bagaimana media sosial dapat dijadikan upaya memperkuat pelembagaan aktivisme digital sebagai wahana pembelajaran pendidikan politik publik. Batasan dalam artikel ini seputar peran dan implikasi relawan politik pasca kontestasi presidensial 2014 dalam ranah politik digital untuk memperkuat pelembagaan aktivisme digital sebagai wahana pembelajaran pendidikan politik publik.

\section{Tipologi Relawan Politik Pasca Elektoral 2014}

Membaca gerakan relawan politik dalam kontestasi presidensial 2014 tentu tidak terlepas dari aktor utama yakni kelas menengah perkotaan. Mengutip studi yang dilakukan Jati, WR (2015) yang menyatakan bahwa dorongan kelas menengah yang secara intens dan instan dalam mengakses media sosial merupakan elemen penting gerakan politik tersebut. Pasalnya, penggunaan media sosial dalam kebutuhan keseharian kelas menengah Indonesia begitu masif. Hal ini menandakan kebutuhan akan akses informasi yang banyak, cepat, dan instan. Berbagai pesan dan informasi yang timbul dalam media sosial itulah yang kemudian diolah menjadi sumber pengetahuan utama bagi kelas menengah Indonesia dalam menilai maupun menanggapi sesuatu. Artinya kehadiran internet dalam demokrasi di Indonesia memang urgen dan signifikan untuk meruntuhkan dindingdinding elitisme dan oligarki kekuasaan

\footnotetext{
belum didukung pengetahuan dan tingkat literasi yang memadai, mereka biasanya belum memahami dengan baik bagaimana seharusnya memanfaatkan ruang publik, untuk tujuan apa, dan tata krama seperti apakah yang harus dipatuhi agar tidak menyinggung pihak lain. Lihat, Sugihartati, Rahma. 10 Februari 2016. Hater di Ruang Publik. Harian Jawa Pos.
} 
yang membatasi partisipasi publik meluas. ${ }^{9}$ Alhasil, peran media sosial dalam ranah politik digital dapat menjadi kekuatan potensial dalam langgam politik Indonesia. Eksesnya telah banyak mengubah rekonfigurasi politik Indonesia, termasuk ikon penting dalam mendorong kemunculan berbagai gerakan aktivisme digital yang kemudian melahirkan fenomena relawan politik dalam kontestasi presidensial 2014.

Dalam mengulas fenomena relawan politik di ranah media sosial kita dapat membaginya menjadi dua kriteria kelompok relawan politik seperti yang sudah dijelaskan sebelumnya yaitu relawan komunitas dan relawan non-komunitas. Relawan komunitas memiliki struktur dan ada pula yang hanya memiliki satu koordinator, hingga struktur kepengurusan dari tingkat pusat dan daerah. Relawan jenis ini juga memiliki nama, tempat dan visi misi organisasi. Beberapa relawan politik yang dapat dikategorikan berasal dari komunitas yakni Jasmev (Jokowi Advanced Social Media Volunteers), Generasi Optimis, Demokreatif, Pro Jokowi (Projo), Sekretariat Nasional Jokowi (Seknas Jokowi) serta beberapa organisasi relawan lainnya. Sedangkan relawan non-komunitas bergerak dan melakukan strategi sendiri secara mandiri. Sebut saja aksi yang dilakukan oleh salah seorang relawan Jokowi di wilayah Nanggroe Aceh Darusalam yang secara mandiri mengelar sebuah kuis melalui media sosial dengan hadiah "sebungkus kopi" kepada para netizen. ${ }^{10}$

Dalam mengatur strategi dan isu yang diambil, kedua kategori relawan ini dalam kontestasi presidensial 2014 memiliki persamaan yakni berusaha memenangi pasangan Jokowi-JK. Akan tetapi pasca

\footnotetext{
9 Jati, WR .(2015). Prospek Politik Digital dalam Kelas Menengah Indonesia. (Online). (http://www.politik.lipi. go.id/kolom/kolom-2/politik-nasional/1012-wasistoraharjo-jati, diakses 5 Mei 2016)

${ }^{10}$ Prast, Hari, dkk. (2014). Demokreatif, Kisah Blusukan Jokowi. Jakarta: Kepustakaan Populer Gramedia (KPG).
}

elektoral 2014, langkah taktis dan strategi yang diterapkan oleh beberapa relawan politik tentulah bergeser sesuai karakteristik masingmasing. Karakteristik tersebut kemudian dapat membedah sikap yang dipilih para relawan yakni sikap aktif atau pasif. Sikap aktif dapat dilihat dari karakteristik para relawan yang tetap konsisten mendukung jalannya pemerintahan Jokowi-JK baik secara online maupun offline. ${ }^{11}$ Akan tetapi, jika dikalkulasi persentase aktivitas para relawan ini dalam mendukung pemerintahan Jokowi-JK lebih banyak berada di ranah online. Jejaring media sosial dipilih sebagai media untuk tetap aktif dengan berupaya menyebarluaskan berbagai informasi seputar pemerintahan Jokowi-JK. Informasi tersebut dapat berupa capaian-capaian kerja kabinet kerja hingga berbagai proyeksi yang akan dilakukan oleh pemerintahan Jokowi-JK. ${ }^{12}$

Sedangkan untuk relawan yang memiliki sikap pasif memang terlihat lebih stagnan. Hal itu ditandai dengan menurunnya aktivitas para relawan ini dalam mendukung dan mengawasi pemerintahan Jokowi-JK. Para relawan ini justru kembali pada rutinitas dan profesi masing-masing. Relawan jenis ini berasal dari semua profesi yang ada di Indonesia. Tidak ayal kemudian pasca kontestasi presidensial 2014, para relawan ini lebih memilih sebagai penonton dan pengamat ketimbang memberikan kritikan terhadap pemerintahan Jokowi-JK. Bahkan ada pula sebagian relawan yang benar-benar melepas perhatiannya terhadap agenda pemerintahan Jokowi-JK. Meski demikian, bukan berarti relawan kategori ini tidak mendukung pemerintahan Jokowi. Pasalnya

\footnotetext{
${ }^{11}$ Dari penelusuran penulis, para relawan yang aktif lebih banyak mendukung, mengawal dan mengawasi pemerintahan Jokowi-JK dalam ranah media sosial (online).

12 Wawancara dengan Retnowidarti Wulandari, salah satu relawan non-komunitas yang tetap aktif mendukung dan menyebarluaskan prestasi dan kinerja pemerintahan Jokowi JK via Whatsapp, 6 Juni 2016 pukul 17.00 WIB.
} 
banyak dari para relawan ini yang kemudian berniat akan kembali menjadi relawan elektoral jikalau sosok Jokowi kembali menjadi calon presiden Indonesia.

Alasan utama kembali ke profesi masingmasing yakni tugas utama guna menghantarkan pasangan Jokowi sudah berhasil dengan baik. Sehingga kedepan sebagai warga negara yang baik adalah mendukung program pemerintah. Bahkan menurut para relawan politik ini dengan kembali ke profesi masing-masing juga merupakan bukti sumbangsih terhadap jalannya pemerintahan Jokowi-JK. Pasalnya relawan ini selalu ingat pesan Jokowi yakni bahwa setelah kontestasi presidensial 2014, "mari kembali ke aktivitas masing masing, yang petani kembali bertani, yang pelajar kembali belajar, yang bekerja kembali ke pekerjaan."13

Deskripsi atas pemilihan sikap pasif para relawan elektoral pasca kontestasi 2015 tentulah tidak selaras dengan studi yang dilakukan Amna \& Ekman (2013), bahwa pemilihan sikap pasif para kaum muda karena minimnya partisipasi dan adanya ketidakpercayaan terhadap dunia politik. ${ }^{14}$ Sebab, hal ini berbeda dengan konteks kaum muda di Indonesia yang ikut terlibat dalam relawan politik. Sikap pasif ini terlihat dari menurunnya aktivitas dalam media sosial untuk mendukung program pemerintah pasca kontestasi elektoral dan bukan karena menurunya ketidakpercayaan politik.

Pemetaan gerakan relawan elektoral ini menunjukan bahwa kelas menengah yang mendominasi relawan tidak semua memiliki kesamaan visi dan misi pasca elektoral. Banyak sekali perbedaan strategi, langkah maupun pendapat dalam mengisi peran dan fungsi

\footnotetext{
${ }^{13}$ Wawancara dengan Ginanjar Rahmawan Tartowiharjo, relawan JASMEV via Facebook, pada 22 Juni 2016, pukul 15.30 WIB.

${ }^{14}$ Amnå, Erik and Ekman. Joakim. (2013). Standby citizens: diverse faces of political passivity. European Political Science Review. FirstView Article. June 2013, pp 121.
}

relawan pasca elektoral 2014. Bahkan, ada pula relawan yang mengklaim bahwa kembali ke profesi masing-masing dan bekerja dengan baik sudah merupakan bukti konkret dalam mengawal Nawacita pemerintahan Jokowi$\mathrm{JK} .{ }^{15}$

Apabila dilakukan perbandingan antara relawan yang memilih sikap aktif dan pasif, ternyata lebih banyak relawan yang memilih sikap pasif ketimbang aktif dalam mendukung kebijakan pemerintahan Jokowi-JK terutama di media sosial. Identifikasi dari sikap pasif ini menjelaskan bahwa relawan politik lebih memilih menjadi gerakan politik disaat kontestasi presidensial 2014 berlangsung, dan kemudian menjadi gerakan sosial pasca kontestasi. Sehingga tidak ayal kemudian para relawan ini dapat disebut sebagai bagian dari tim sukses Jokowi-JK.

\section{Strategi Relawan Politik}

Pasca kontestasi presidensial 2014 gairah kegembiraan politik tetap terasa, terutama dalam langgam politik digital. Hal itu dapat dilihat dari geliat para relawan yang tetap aktif mewarnai langgam politik digital Indonesia. Meski demikian jika ditelaah melalui percakapan di timeline media sosial pasca kontestasi elektoral 2014, tensi gerakan relawan tidak begitu masif ketimbang saat kontestasi elektoral 2014. Dari sini kemudian penulis menemukan ada beberapa strategi para relawan politik pasca kontestasi elektoral 2014, yakni mengambil peran intra-parlementer dan ekstra-parlementer untuk mengawal pemerintahan Jokowi-JK bersama-sama rakyat. Adapun beberapa peran tersebut diantaranya:

\footnotetext{
${ }^{15}$ Wawancara dengan Dyah Kartika Rini Djoemadi, Koordinator relawan JASMEV dan Komisaris Danareksa 12 April 2016 di Yogyakarta.
} 


\section{Peran Intra-parlementer}

Peran intra-parlementer seringkali ditafsirkan melakukan aktivitas politik dalam lingkup institusi yakni pemerintahan Jokowi-JK. Beberapa aktivitas politik yang diambil dalam intra-parlementer adalah turut berupaya mengulirkan dokumen Nawacita dan gerakan revolusi mental dalam langgam politik Indonesia. Artinya peran ini diambil dengan tujuan mengawal dan membantu kelancaran pemerintahan Jokowi-JK. Peran ini ditujukan untuk menjelaskan bahwa posisi para relawan tidak saja sebagai pengembira politik maupun tim sukses semata, akan tetapi lebih dari itu juga turut membangun kelancaran dan kesuksesan pemerintahan Jokowi-JK.

Itu mengapa beberapa elite relawan politik mau menerima jabatan publik dalam pemerintahan Jokowi-JK. Berikut beberapa nama relawan politik yang mendapat jabatan dalam pemerintahan Joko Widodo, diantaranya; Darmin Nasution (Komisaris Bank Mandiri), Cahaya Dwi Rembulan Sinaga (Komisaris Bank Mandiri), dan Diaz Hendroprijono (Komisaris Telkomsel), Hilmar Farid (Komisaris PT Krakatau Steel), Paiman Rahardjo (Komisaris Perusahaan Gas Negara), Pataniari Siahaan (Komisaris Independen BNI), Refly Harun (Komisaris Jasa Marga), Roy E Maningkas (Komisaris PT Krakatau Steel), Hironimus Hilapok (Komisaris PT Adhi Karya), Goei Siauw Hong (Komisaris Bank Mandiri), Jeffry Wurangian (Komisaris BRI), Dyah Kartika Rini Djoemadi (Komisaris Independen Danareksa), Boni Hargens, (Komisaris Kantor Berita Nasional Antara), serta beberapa nama relawan lainnya. Hanya Direktur Eksekutif Soegeng Sarjadi Syndicate Sukardi Rinakit, yang juga dikenal sebagai pengamat politik kemudian mengundurkan diri dan lebih memilih menjadi staf khusus Menteri Sekretaris Negara bidang politik dan pers, dengan alasan tidak memiliki kompetesi di bidang perbankan. Selain itu ada pula relawan non-komunitas lainnya yang juga mendapatkan berbagai jabatan publik seperti Duta Besar Luar Biasa dan Berkuasa Penuh (LBBP) untuk 10 negara sahabat. Dari 10 Duta Besar yang dilantik tersebut salah satunya merupakan Dewan Pakar Hubungan Internasional relawan Seknas Jokowi, Helmy Fauzi. Bahkan terdapat 33 nama calon duta besar (Dubes) RI yang sepertiganya (11 orang) merupakan mantan anggota tim relawan Jokowi-JK dalam pemilihan presiden 2014. $(19 / 8 / 2015){ }^{16}$

Adapun beberapa argumentasi yang dibangun para relawan elektoral memilih sikap intra-parlementer dengan masuk dalam pemerintahan Jokowi-JK diantaranya; Pertama, ingin membuktikan bahwa para relawan bukan hanya berjuang untuk memenangkan Jokowi$\mathrm{JK}$, tetapi lebih dari itu juga turut mengawal agenda Nawacita. Artinya, para relawan tidak hanya ingin disebut sebagai tim sukses akan tetapi lebih dari itu sebagai relawan politik yang terus mengawal pemerintahan. Salah satu wujud nyata para relawan intra-parlementer yakni dengan mendirikan Forum Padamu Negeri. Adapun anggotanya yaitu Komisaris yang tergabung dalam Forum Bagimu Negeri sebagai berikut: Hilmar Farid (Komisaris Krakatau Steel), Kartika Djoemadi (Komisaris Danareksa), Teddy Wibisana (Komisaris Indofarma), Victor Sirait (Komisaris Waskita Karya), Margiyono (Komisaris Telkom), Sonny Subrata (Komisaris Semen Indonesia), Nick Nurrahman (Komisaris Wijaya Karya), Michael Umbas (Komisaris Hotel Indonesia Natour), Diaz Hendropriyono (Komisaris Telkomsel), Arie Coerniadi (Komisaris BTN), Taufan Hunneman (Komisaris JICT), Razif (Komisaris Balai Pustaka). ${ }^{17}$ Forum ini bertujuan agar para komisaris yang berasal dari relawan politik yang ditugaskan Presiden Jokowi meski tidak

\footnotetext{
${ }^{16}$ Susilo, Djokowi. 19 Agustus 2015. Ketika Relawan Menjadi Dubes RI. Harian Jawa Pos.

${ }^{17}$ Nawacitanews.com. (2015). (Online). Forum Bagimu Negeri Dibentuk Sebagai Pengawal Nawacita di BUMN. (http://www.nawacitanews.com/forum-bagimu-negeridibentuk-sebagai-pengawal-nawacita-di-bumn, diakses Januari 2016)
} 
sebagai eksekutor tetapi sebagai pengawas dan penjaga Nawacita di BUMN. Kedua, bertujuan untuk membenahi dari berbagai kepentingan yang selama ini menggerogoti kinerja dan pendapatan BUMN. Pembenahan ini meliputi pengembangan teknologi, manajemen sumber daya manusia serta mengikis mental proyek yang seringkali mendominasi banyak BUMN.

Hadirnya argumentasi utama para relawan politik ingin berjuang dalam intraparlementer karena didasari bahwa selama ini BUMN terkesan sebagai sumber pendapatan bagi para penumpang gelap. Bahkan banyak mafia yang seringkali meminta upeti dari BUMN. Oleh sebab itu, langkah memilih gerakan intra-parlementer dapat menjadi salah satu langkah taktis untuk mengikis mafia BUMN yang selama ini seringkali mendominasi banyak elite BUMN. Sehingga dengan langkah taktis ini kedepan BUMN dapat kembali tumbuh menjadi salah satu kekuatan ekonomi bangsa. ${ }^{18}$

\section{Peran Ekstra-parlementer}

Peran ekstra-parlementer dipilih dengan tujuan sebagai pengawas dan penyeimbang terhadap kekuasaan negara atau pemerintahan Jokowi-JK. Peran ini berusaha membangun karakter ekstra-parlementer yang dalam konteks ini dapat dilihat sebagai aktivitas politik yang diselenggarakan oleh kelompok-kelompok diluar institusi-institusi tersebut. Langkah taktis tersebut diharapkan dapat menghasilkan beberapa hal diantaranya; (1) mempengaruhi (influencing) proses pelaksanaan kebijakan publik, (2) mengawasi (monitoring) proses pelaksanaan kebijakan public, (3) memberikan penilaian (evaluating) pelaksanaan kebijakan publik, dan (4) memberikan bantuan dan pembelaan (advocacy) terhadap kelompok-kelompok yang dirugikan atas pelaksanaan kebijakan publik. ${ }^{19}$

\footnotetext{
${ }^{18}$ Wawancara dengan Dyah Kartika Rini Djoemadi, Komisaris Danareksa dan Koordinator relawan JASMEV

${ }^{19}$ Fikri AF, Akhmad (1999). Menjadi Politisi Ekstra
}

Selain itu ada beberapa hal yang perlu dibangun oleh para relawan politik dalam posisi sebagai kelompok ekstra-parlementer, yaitu Pertama, relawan politik diharapkan menawarkan wacana pemikiran alternatif di tingkat ideologi sebagai jalan alternatif bagi konsep kebijakan publik yang dikeluarkan oleh pemerintahan. Kedua, relawan politik dituntut bukan sekadar hanya mampu berwacana, melainkan juga memberikan contoh nyata konkret mengenai penerapan di lapangan. Terutama para relawan yang telah menjadi buzzer politik dengan follower ribuan..$^{20}$ Ketiga, relawan politik diharapkan mampu menyediakan berbagai informasi yang berguna bagi publik terutama seputar kebijakan pemerintahan. Informasi ini sejatinya mampu menjadi suplemen bagi pemberdayaan, pendidikan politik melalui jejaring diskusi secara reguler-baik yang dimulai dari kota

Parlementer. Yogyakarta: Penerbit LKIS.

${ }^{20}$ Dalam langgam politik digital istilah buzzer politik merupakan sebuah aktivitas pemasaran politik yang berisi informasi pada saluran komunikasi digital untuk menciptakan efek mempengaruhi dan menjadi perbincangan luas (viral) hingga kemudian menjadi opini publik. Ada dua kategori buzzer dalam politik digital yakni; Pertama, volunteers buzzer, berasal dari netizen yang bersedia secara sukarela menjadi relawan politik digital. Dikarenakan tugas relawan digital adalah untuk menyebarkan informasi perihal calon yang didukung, maka secara otomatis para relawan ini kemudian menjadi buzzer politik. Akan tetapi para buzzer ini tidak menerima bayaran karena merupakan bagian relawan digital yang mengedepankan semangat voluntarisme. Kedua, independent buzzer, berasal dari para netizen yang memiliki sifat netral dan tidak memiliki keberpihakan apapun baik ideologi maupun program kerja sang calon. Dengan sifat yang netral membuat ada sebagian besar rentan beralih profesi menjadi buzzer yang berwatak pragmatis. Artinya, para buzzer ini kemudian bergerak sesuai dengan tuntutan para pembayar dan penyewa. Para buzzer ini seringkali mematok tarif sesuai dengan banyaknya follower yang dimiliki dan tingkat kesulitan yang dihadapi. Kedua tipologi buzzer ini memiliki kreativitas dan inovasi yang sama dalam mengunggah postingan hingga memberikan efek mempengaruhi bagi netizen lainnya untuk bertindak sama dengan nalarnya. Biasanya para buzzer politik ini menggunakan akun anonim dan real baik di Twitter, Facebook, Instagram dan Youtube. Lihat, Arianto, Bambang. 28 Februari 2016. Buzzer Politik dan Informasi Hoax. Harian Kedaulatan Rakyat. 
sampai ke komunitas-komunitas basis di desa. Kondisi ini dapat menciptakan suasana dan mendorong orang saling berdiskusi dan melahirkan partisipasi aktif. Keempat, relawan politik dapat memainkan peran sebagai pemimpin perubahan. Hal itu disebabkan karena para relawan politik dapat bergerak bebas dan tidak terikat oleh partai politik tertentu. Bahkan, para relawan politik dapat dengan mudah untuk membubarkan diri. ${ }^{21}$ Peran-peran inilah yang kedepan harus dapat terus dilembagakan oleh para relawan politik dalam mengawal dan mengawasi pemerintahan Jokowi-JK. Hal yang sama juga diutarakan oleh salah satu relawan Jokowi Advanced Social Media Volunteers (JASMEV) yang tetap aktif mengawal pemerintahan Jokowi JK hingga saat ini:

"saya tetap ikut ambil bagian menjadi relawan politik, karena sosok Jokowi merupakan tokoh yang sangat mementingkan rakyat kecil, saya percaya bahwa Indonesia akan menjadi lebih baik bila dipegang oleh sosok Jokowi. Untuk itu saya berbuat semaksimal mungkin untuk membantu sosok pilihan saya seperti Jokowi." (wawancara dengan Iswandi F Tanjung, koordinator wilayah JASMEV DKI Jakarta)

Penelaahan di ranah politik digital banyak langkah taktis yang diambil oleh para relawan baik non-komunitas dan komunitas. Dalam penelitian ini, penulis lebih menfokuskan kepada relawan politik yang lebih banyak bergerak di media sosial, sebut saja JASMEV. Relawan politik digital ini seringkali menggunakan media sosial dalam komunikasi politiknya, baik melalui Facebook maupun Twitter. Ada beberapa bentuk upaya JASMEV untuk tetap aktif diranah politik digital dengan mengambil peran ekstra parlementer seperti contoh dibawah ini.

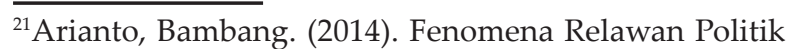
Dalam Kontestasi Presidensial 2014. Jurnal Ilmu Sosial dan Ilmu Politik. Vol. 18, No. 2 Edisi November.
}

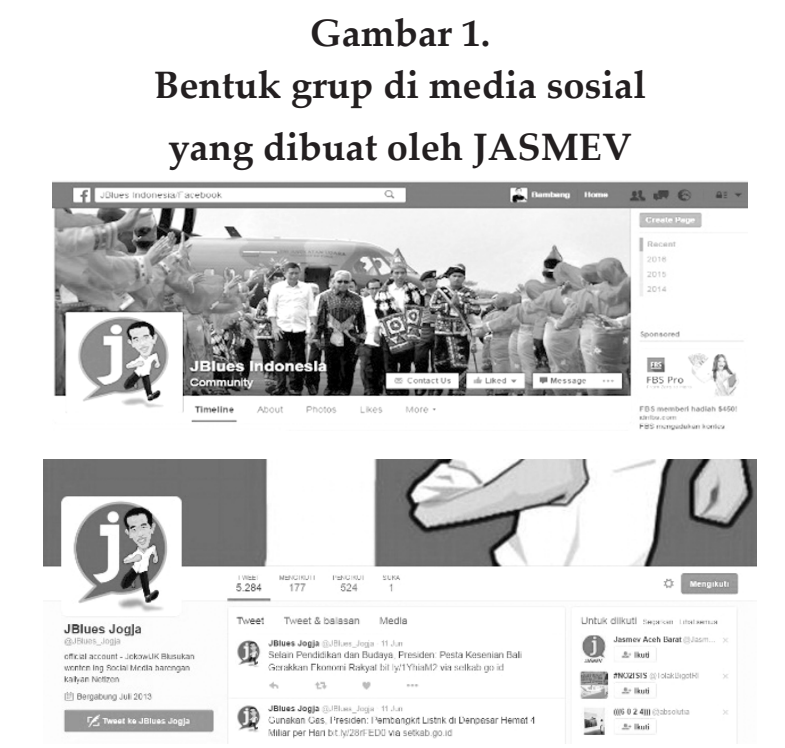

Sumber: akun Facebook dan Twitter Jblue Community

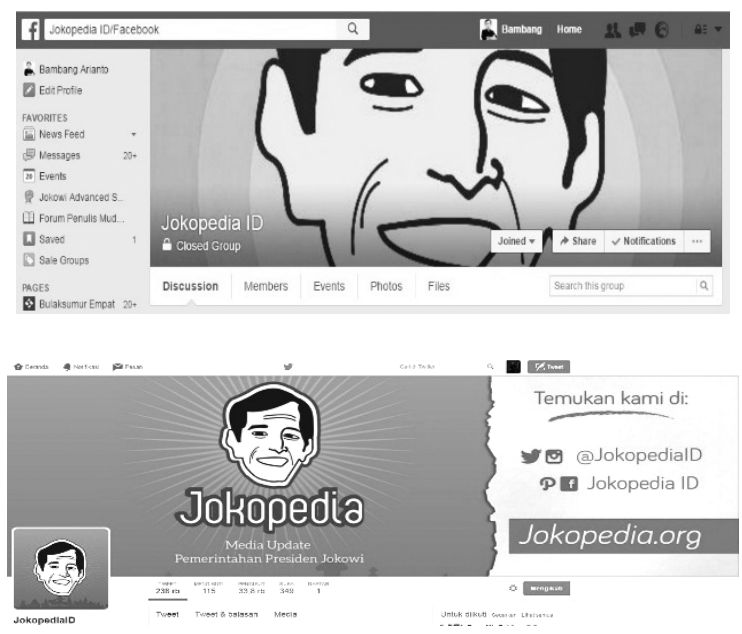

Sumber: Fanpage Jokopedia di Facebook dan Twitter

Dilihat dari akun Jokopedia dan Jblues (Jokowi Blusukan) yang digunakan oleh JASMEV terlihat sekali konten akun tersebut lebih banyak berisikan materi dari program pemerintahan Jokowi-JK. Selain itu, kedua akun ini juga sering mengadakan diskusi secara online, yang bertujuan mengasah wacana para netizen terutama dalam isu-isu politik dan pemerintahan. Salah satu tematik diskusi berupa capaian-capaian dari kinerja kabinet yang selalu di tampilkan setiap saat di timeline. Selanjutnya tampilan yang diunggah kedua akun ini bukan saja bersifat 


\section{Gambar 2.}

Beberapa meme yang diunggah akun Jokopedia
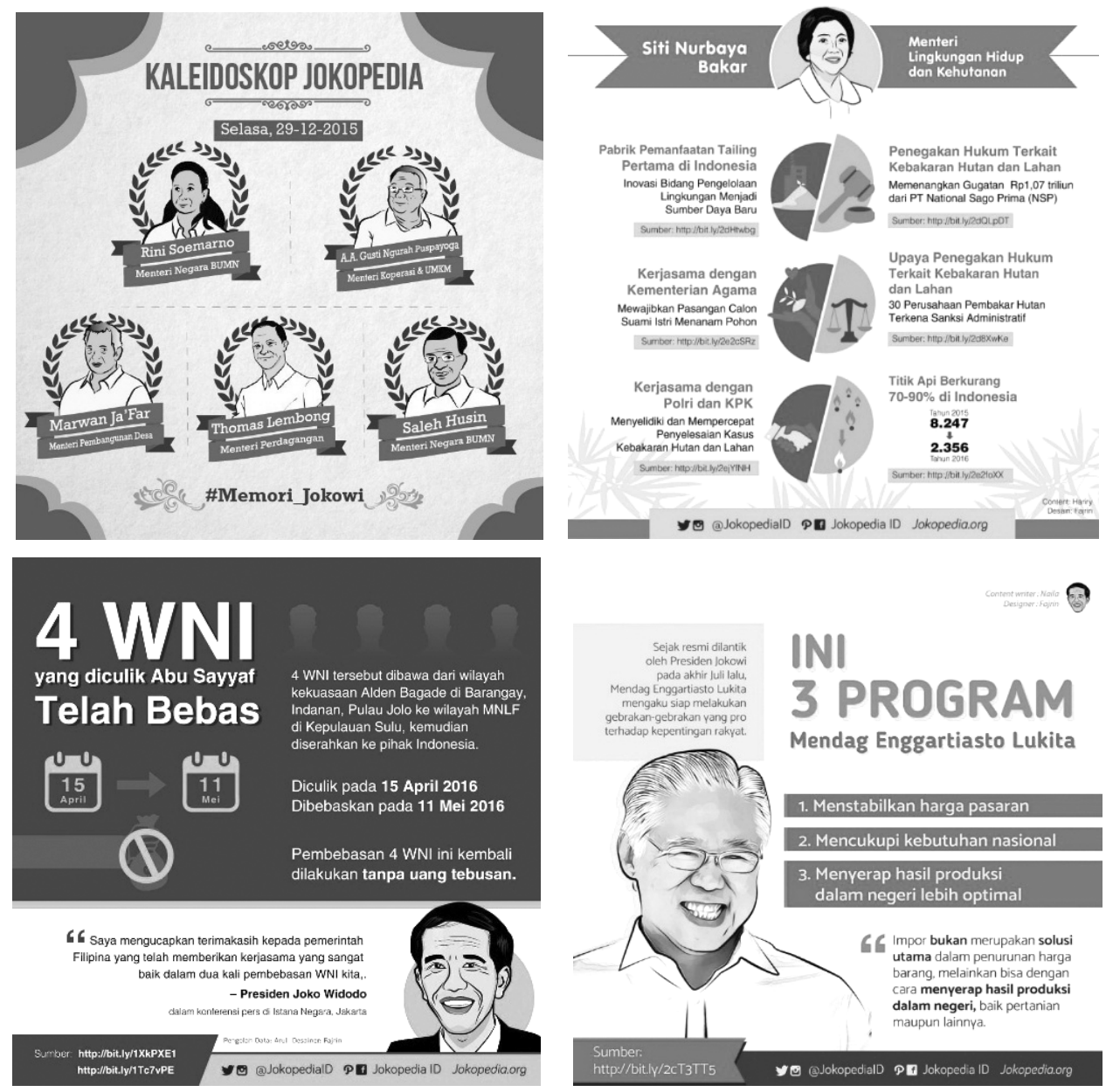

Sumber: Jokopedia.org

informasi, tetapi juga banyak yang berupa meme politik $^{22}$ seputar keberhasilan pemerintahan Jokowi-JK. Berikut beberapa contoh meme dari Jokopedia yang diunggah di media sosial.

Keberadaan akun JBlues dan Jokopedia di ranah media sosial terlihat sangat aktif. Hal itu tampak dari banyaknya para netizen yang melakukan retwett, maupun mengunggah ulang berbagai informasi yang ditampilkan oleh akun

\footnotetext{
${ }^{22}$ Meme politik atau juga dikenal "meme comics" merupakan sebentuk tiruan dari berbagai gambar yang telah dikenal akrab (familiar) oleh kalangan pengguna internet (netizen). Dengan demikian, meme comis sekadar hasil jiplakan, montase atau rekayasa visual dari sejumlah gambar yang telah populer. Lihat Lukmantoro, Triyono. (2015). Komunikasi Politik di Era Digital. Jakarta: Universitas Multimedia Nusantara Press.
}

Jokopedia dan JBlues. Hal inilah yang sedikit membedakan dengan geliat para relawan politik di belahan Amerika Serikat yang mana pasca kontestasi elektoral, lebih banyak memilih sikap pasif dalam mengawasi jalannya pemerintahan. Artinya, bila dilihat dari peran dan proyeksi relawan politik terutama di media sosial, gejala ini telah mengonfirmasi bila para relawan dalam konteks Indonesia tidak hanya menjadi relawan elektoral atau tim sukses pemenangan Jokowi-JK semata. Akan tetapi lebih dari itu para relawan ini turut mengambil peran ganda baik intra maupun ekstra-parlementer dalam upaya membangun pemerintahan yang lebih berpihak kepada rakyat.

Akan tetapi yang menjadi probematika adalah ketika para relawan berperan ganda 
antara peran intra maupun ekstra-parlementer. Sebab, kita pahami bersama bahwa tugas utama para relawan adalah meneliti sebabakibat dari kinerja kebijakan dan program publik. Terutama, soal apakah suatu kebijakan publik dibuat berdasarkan pertimbanganpertimbangan yang matang atau hanya diputuskan sepihak untuk memenuhi kepentingan politik semata. Artinya, peran ganda ini sedikit banyak akan menimbulkan dilema yang kemudian menjadi bumerang bagi masa depan para relawan. Apalagi karakter para relawan pendukung Jokowi-JK sangat beragam. Sehingga sulit bila kemudian para relawan dapat berperan ganda baik di wilayah intra dan sekaligus ekstra-parlementer.

Oleh sebab itu, langkah taktis untuk meminimalisir dilema tersebut adalah dengan tetap mendorong nalar politik para relawan terutama yang masih aktif untuk dapat tetap mengedepankan dan mendengarkan suara publik terutama netizen. Artinya, jika pemerintahan Jokowi-JK ada mengulirkan kebijakan yang tidak pro rakyat, maka secara otomatis para relawan dituntut berani mengkritik secara argumentatif, meskipun kebijakan itu digulirkan oleh para elite relawan yangduduk di pemerintahan Jokowi-JK. Dengan demikian, langkah taktis ini setidaknya dapat tetap mengembalikan hakikat peran relawan sebagai pengawal suara rakyat. Akhirnya dari kedua pilihan aktif dan pasif ini dapat ditarik kesimpulan bahwa pilihan relawan untuk memilih sikap pasif pasca kontestasi elektoral dapat dikategorikan sebagai relawan elektoral karena bersifat insindental. Sedankan pilihan aktif pasca kontestasi elektoral dapat disebut sebagai relawan politik karena tetap aktif sebagai relawan dalam menyebarkan isu-isu politik dan pemerintahan.

\section{Pelembagaan Aktivisme Digital}

Penyelenggaraan pemilu ke pemilu di Indonesia sampai saat ini, menunjukkan jumlah golongan putih (golput) semakin meningkat.
Gerakan golput ini dimotori oleh sekelompok aktivis pro demokrasi pada awal Orde Baru. Salah satu motor penggeraknya adalah Arief Budiman. Tercatat pada Kamis, 3 Juni 1971, Arief Budiman yang didampingi eksponen generasi muda, seperti Imam Waluyo, Julius Usman, Husin Umar dan beberapa aktivis lain memproklamirkan gerakan moral yang dinamakan Golongan Putih (Golput). Akhirnya, gerakan golput dianggap sebagai kekuatan simbolik perlawan terhadap rezim Orde Baru. ${ }^{23}$ Pemilu 2009 silam golput mencapai puncaknya, seperti digambarkan oleh tabel dibawah ini.

Tabel 1.

Gambaran Golongan Putih (Golput) dalam Kontestasi Elektoral di Indonesia

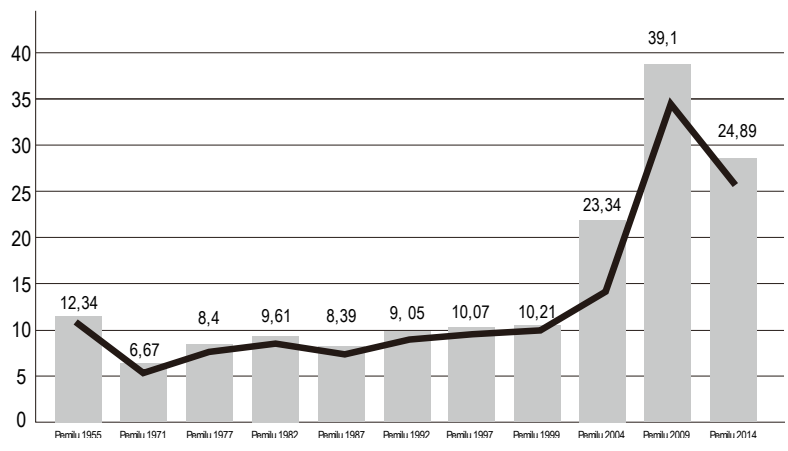

Sumber: diolah oleh penulis dari data golongan putih Pemilu 1999-2014

Dalam historiografi politik Indonesia, fenomena golput seringkali dilihat sebagai ekspresi ketidakpuasan atau kekecewaan demokratik (democratic dissatifiction). Jika dibandingkan dengan yang berlangsung selama Orde Baru, fenomena golput pascareformasi memang cenderung meningkat dari Pemilu ke Pemilu. Seperti, dari 10 persen pada tahun 1999, naik menjadi 23 persen pada 2004, dan melonjak lagi menjadi 39 persen pada 2009. Beruntung pada Pemilu 2014 mengalami penurunan menjadi 24,89 persen. ${ }^{24}$

\footnotetext{
${ }^{23}$ Nyarwi. (2009). Golput Pasca Orde Baru: Merekonstruksi Ulang Dua Perspektif. Jurnal Ilmu Sosial dan Ilmu Politik. Vol. 12 No. 3 Edisi Maret.

${ }^{24}$ Viva.co.id. (2014). Angka Golput Menurun di Pemilu
} 
Gambaran fluktuasi golput pada Pemilu 2009, menegaskan bahwa publik sudah cukup pesimis dengan figur-figur yang diusung oleh partai politik untuk memperbaiki kondisi bangsa. Apalagi, pasca reformasi preferensi politik Indonesia telah beralih dari partai politik (parpol) menuju figur. Artinya, figur dan ketokohan sangat berpengaruh kuat terhadap kultur politik Indonesia. Hal ini didasari oleh perilaku pemilih Indonesia yang kerap dipengaruhi elektabilitas figur, yang nantinya akan berkorelasi positif pada elektabilitas parpol. Pemilih kemudian akan lebih memilih partai bukan karena daya tarik partai dan programnya, melainkan lebih pada ketertarikan sosok figur yang diusung. Akan tetapi semenjak kehadiran media sosial, publik tidak lagi dibodohi dengan figurfigur hiperealitas meskipun saat ini tengah menguatnya personalisasi politik dalam kultur politik Indonesia. Bahkan melalui media sosial publik dapat turut berpartisipasi dalam pertukaran informasi dan memperdebatkan cara pandang mereka mengenai beragam isu yang penting dalam kehidupannya. ${ }^{25}$ Artinya media sosial kian membuka ruang baru bagi penggunanya. Ruang tersebut berupa dimensi yang masih bersifat netral yang belum ada komponen-komponen yang mengisinya. ${ }^{26}$ Dimensi ini yang kemudian banyak mempengaruhi publik dalam memilih figur dan kandidat politik Itu mengapa kemudian, ruang tersebut telah banyak mendorong hadirnya para aktivis dan pegiat media sosial.

2014. (Online). (http://politik.news.viva.co.id/news/ read/503322-angka-golput-menurun-di-pemilu-2014, diakses 15 Juni 2015)

${ }^{25}$ Nugroho, Y., \& Syarief, S. S. (2012). Seri fesmedia Asia: Melampaui Aktivisme click? Media Baru dan Proses Politik dalam Indonesia Kontemporer. Jakarta: Friedriech-EbertStiftung Kantor Perwakilan Indonesia.

${ }^{26}$ Dewantara dkk. (2015). Aktivisme dan Kesukarelawanan dalam Media Sosial: Komunitas Kaum Muda Yogyakarta. Jurnal Ilmu Sosial dan Ilmu Politik. Vol. 19, No. 1 Edisi Juli.
Beberapa hal yang menyebabkan fenomena pelembagaan aktivisme digital semakin menguat dalam langgam politik Indonesia, diantaranya; Pertama, pemanfaatan media sosial untuk menanggapi isu-isu dalam berbagai bidang turut mendorong kehadiran aktivisme digital dalam langgam politik Indonesia. Kedua, kehadiran fenomena aktivisme digital dalam ranah politik digital lebih disebabkan oleh banyaknya saluran partisipatoris yang tersumbat. Sebut saja partai politik yang sejatinya berperan sebagai penyampung aspirasi publik, tetapi nyatanya seringkali bersikap bungkam. Dalam konteks ini aktivisme digital merupakan bagian dari bentuk aktualisasi dari praktik politik digital dalam masyarakat. Adapun pengertian politik digital memiliki pengertian multi interpretatif, namun demikian kristalisasi dari berbagai macam konsep tersebut kemudian merujuk pada terbentuknya ruang publik dalam dunia maya (Cyberspace) (Postil, 2012). Ruang tersebut adalah arena non struktural, dinamis dan egaliter yang memungkinkan semua orang untuk berpartisipasi dan berpendapat melalui jejaring online. ${ }^{27}$

Menurut studi Hamid (2014) bahwa netizen Indonesia juga sudah terbentuk secara signifikan. Bahkan dalam skala dunia, orang-orang Indonesia dikenal sebagai pengguna Facebook terbesar keempat dan pengguna Twitter terbesar kelima. Tetapi besarnya pengguna media sosial di Indonesia masih didominasi oleh kelas menengah yang kemudian mulai menggeser pengaruh media konvensional. Kelas menengah inilah yang kemudian lebih cepat beradaptasi dengan ranah digital. Salah satu karakter kelas menengah ini adalah mengedepankan penggunaan ranah digital (online) daripada offline. Karakter

\footnotetext{
${ }^{27}$ Jati, WR. (2015). Cyberspace, Internet dan Ruang Publik Baru: Aktivisme Online Politik kelas Menengah Indonesia. Jurnal Pemikiran Sosiologi. (Online). (http://jps. fisipol.ugm.ac.id/index.php/jps/article/view/34, diakses 10 januari 2016)
} 
ini yang menyebabkan pemberitaan media konvensional lebih banyak mengadopsi atau bersumber dari media sosial. Bahkan, kelas menengah ini yang menjadi inisiator utama kehadiran relawan media sosial yang turut mendorong hadirnya aktivisme digital. Pasalnya tahapan aktivisme digital menurut studi Jati, WR (2015) meliputi beberapa tahapan yakni political awareness (kesadaran politik), political engagement (keterikatan politik), dan kini political activism (aktivisme politik). Hal itu mengonfirmasi pernyataan relawan yang tetap aktif di media sosial hingga saat ini, bahwa sosok Jokowi membuat dirinya ingin terus aktif memberikan informasi kepada teman sejawat maupun koleganya baik Twitter maupun Facebook. Tujuan agar kolega dan jejaring pertemanan dapat mengetahui sosok dan figur pemimpin impiannya. ${ }^{28}$

Bentuk dari pelembagaan aktivisme digital yang digulirkan para relawan bersama pemerintahan Jokowi-JK adalah bersama-sama menyebarkan informasi seputar capaian dan prestasi dari pemerintahan Jokowi-JK hingga kemudian informasi ini menjadi trending topic. Sebut saja, dalam memperingati tahun kedua pemerintahan Jokowi-JK para relawan menyebarkan berbagai meme politik dengan tagar \#KE2JANYATA.

Berikut beberapa contoh meme politik yang disebar para relawan sebagai bentuk pelembagaan aktivisme digital :

\footnotetext{
${ }^{28}$ Wawancara dengan Retnowulandari, Relawan nonkomunitas Jokowi asal Kota Bogor via Facebook pada 9 Juni 216 Pukul 21.30 WIB
}
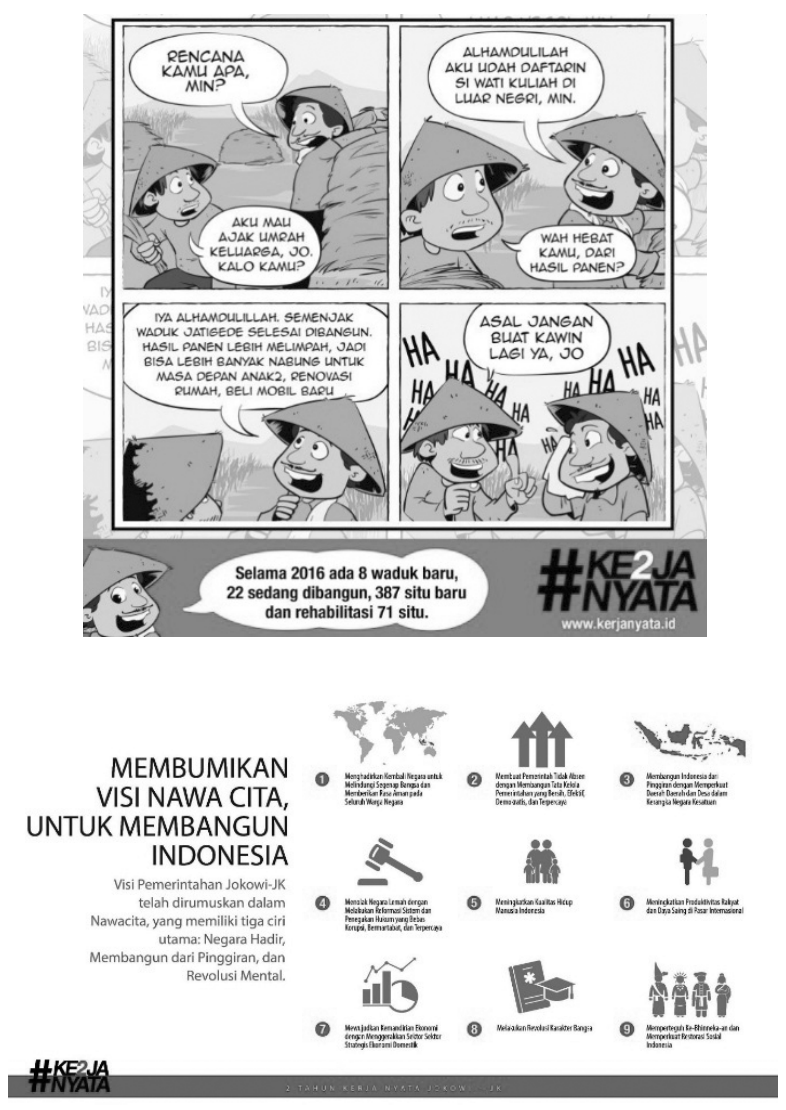

Sumber : www.kerjanyata.id

Gambaran inilah yang kemudian turut mendorong menguatnya aktivisme digital. Dalam konteks ini aktivisme digital terbagi menjadi dua kategori yakni, practical activism dan slacktivism. Yang mana practical activism sebagai aktivitas melalui media sosial secara langsung, proaktif hingga berlawanan dalam mencapai perubahan sosial. Sedangkan slacktivism didefinisikan sebagai aktivitas melalui media sosial, yang tujuannya adalah untuk meningkatkan kesadaran, menghasilkan perubahan, atau memberikan kepuasan kepada pihak lain agar dapat terlibat dalam informasi ini. ${ }^{29}$ Artinya aktivisme digital yang digulirkan para relawan mendekati slacktivisme yang bertujuan meningkatkan kepedulian,

\footnotetext{
${ }^{29}$ Rotman, D., Viewe, g. S., Yardi, S., Chi, E., Preece, J., Shneiderman, B., Glaisyer, T. (2011). From slacktivism to activism: participatory culture in the age of social media. Proceedings of the 2011 annual conference extended abstracts on Human factors in computing systems. New York, NY, USA: ACM.
} 
kesadaran guna mendorong sebuah perubahan bagi publik terutama dalam isu-isu politik dan pemerintahan.

Dengan semakin menguatnya pelembagaan aktivisme digital dapat menyebabkan terjadinya perluasan ruang publik politik yang mentransformasikan kesadaran politik personal ke ruang publik baru yang terbuka secara lebih interaktif. Sekaligus berpotensi memperbarui minat atau kepentingan pada keterlibatan dan partisipasi warga. Keterlibatan warga mencakup tiga dimensi, yakni pengetahuan politik (apa yang dipahami masyarakat mengenai masalah publik), kepercayaan politik (orientasi publik untuk mendukung sistem politik), dan partisipasi politik (kegiatan konvensional yang didesain untuk mempengaruhi pemerintah dan proses-proses pembuatan keputusan). ${ }^{30}$ Alhasil, pelembagaan aktivisme digital ini sekurang-kurangnya dapat menekan apatis publik, sekaligus menghadirkan pendidikan politik yang dapat dipahami dengan mudah sehingga mampu menjadi alat penyadaran politik bagi publik.

\section{Wahana Pendidikan Politik Publik}

Peran ganda para relawan politik yang kemudian dapat mendorong kehadiran fenomena aktivisme digital dapat menjadi salah satu bagian dari suplemen pendidikan politik. Jika ditelisik pendidikan politik mulai dijalankan oleh pemerintah di era revolusi Indonesia (1945-1950), Demokrasi Liberal (1950-1959), Orde Lama (1959-1966), Orde Baru (1966-1998), hingga Orde Reformasi (1998sekarang). Pendidikan politik yang diterapkan oleh masing-masing pemerintahan tersebut memiliki keunikan tersendiri, sekaligus menjadi cermin pembelajaran politik bagi pemerintahan

\footnotetext{
${ }^{30}$ Hamid, Veronica. (2014) Merancang Arah Baru Demokrasi, Indonesia Pasca Reformasi: Angin Harapan Demokrasi Digital, Nostalgia Demokrasi Klasik, Transformasi Ruang Publik dan Politisasi Media Sosial. Jakarta: Kepustakaan Populer Gramedia (KPG).
}

di masa mendatang. Pendidikan politik di awal masa kemerdekaan merupakan "patriotic political education" dan lebih memberikan penekanan pada "nation and characater building". Pendidikan politik di masa Orde Lama (19591966) dibangun oleh pemerintahan Presiden Soekarno. Kala itu, pendidikan politik lebih diarahkan pada pemahaman dan kesadaran politik, namun akhirnya diselewengkan menjadi pendidikan yang bersifat "indoktrinatif". ${ }^{31}$ Adanya pengangkatan Presiden seumur hidup kala itu, menjadi salah satu bentuk carut-marut pendidikan politik. Selama Orde Baru (19661998), pendidikan politik juga dijalankan guna memenangkan dan memperkokoh kekuasaan, bukan proses penyadaran berpolitik. Rakyat saat itu digiring kebilik-bilik suara guna memberikan dukungan penuh pada partai tertentu, sedangkan kebebasan berpolitik rakyat tetap terpasung. Artinya, selama ini pendidikan politik hanya diberikan sebatas pada kajian fakta dan bukan konsep dasar. Materi substansial seringkali direduksi sehingga konsep pendidikan politik menjadi monoton. Gejala inilah yang kemudian menjadi indikator bahwa tengah terjadi disfungsi pendidikan politik. Padahal pembelajaran politik sejatinya dapat dilanjutkan dengan implementasi politik pada sektor dimana kekuasaan dapat dimengerti oleh rakyat secara rasional. Itu mengapa, ketika publik berhadapan dengan permasalahan politik praktis, yang terjadi adalah menjamurnya sikap apatis publik tanpa mengerti apa yang harus dilakukan. Gejala apatis politik ini yang dapat membahayakan pelembagaan demokrasi.

Kehadiran media sosial banyak mengikis apatis politik dalam nalar publik. Media sosial telah banyak mendorong publik untuk ikut larut mengikuti isu-isu politik pemerintahan, dengan suasana yang lebih luwes, santai dan menyenangkan. Hal itu dibuktikan dengan

\footnotetext{
${ }^{31}$ Somantri, Muhammad Numan. (2001). Menggagas Pembaharuan Pendidikan IPS. Bandung: Penerbit Remaja Rosdakarya.
} 
postingan, komentar maupun meme politik yang lebih terasa ringan dan cepat dimengerti oleh publik. Artinya, peran relawan politik yang mendorong pelembagaan aktivisme digital dapat menjadi salah satu suplemen pendidikan politik. Pasalnya kapasitas informasi yang disediakan oleh media sosial sangat memungkinkan publik lebih cepat memiliki berbagai pengetahuan tentang informasi politik dan pemerintahan. Dengan langkah taktis ini pemahaman politik yang selama ini terdistorsi dapat terus direduksi dari peta kognitif rakyat Indonesia.

Fenomena aktivisme digital yang digerakan oleh para relawan politik pasca kontestasi elektoral 2014 ternyata mengundang perhatian banyak pihak. Terutama pemerintahan JokowiJK yang kemudian segera mengambil peran dalam upaya pelembagaan aktivisme digital. Hal itu dapat dilihat dari upaya Presiden Jokowi meluncurkan akun Youtube resminya (28/05/2016) di istana Bogor. Akun dengan nama http:// youtube.com/c/jokowi telah mengkonfirmasi bahwa Presiden Jokowi berupaya memanfaatkan politik digital untuk lebih mendekatkan diri kepada relawan dan rakyatnya sekaligus melembagakan aktivisme digital bagi wahana pendidikan politik publik.

Gejala ini kemudian mengajak kita untuk mencermati bahwa pola aktivisme digital dapat menjadi wahana pembelajaran pendidikan politik publik dikarenakan beberapa hal diantaranya; Pertama, partisipasi publik yang muncul dalam setiap laporan riil masyarakat dapat menjadi salah satu bentuk aktivisme dalam membangun budaya partisipatorisme untuk kebaikan bersama. Sekaligus dapat digunakan untuk menjelaskan proses desentralisasi yang membawa pemerintahan Jokowi-JK lebih dekat kepada rakyat dan relawan, terutama soal proses pengawasan dan pengambilan kebijakan publik dalam wilayah isu spesifik berskala lokal. Artinya pelembagaan aktivisme digital dapat berpotensi menjadi media perantara sekaligus wahana penyebarluasan gagasan politik antara rakyat dan pemerintahan Jokowi-JK. Kedua, geliat aktivisme digital sebagai wahana komunikasi dialogis antara pemerintahan Jokowi-JK dengan publik yang dapat memperkuat perbaikan kesadaran tentang hak-hak politik kewargaan yang kemudian menjadi arena pembelajaran pendidikan politik. Artinya, langkah taktis ini menjadi salah satu ikon dalam mempercepat proses transfer pendidikan politik kepada publik secara komprehensif, sehingga publik akan semakin rasional dan cerdas karena tidak lagi disuguhi oleh banyak pembelajaran politik yang hanya bersifat parsial serta insidental. Ketiga, aktivisme digital dapat menciptakan ranah politik digital sebagai wahana kegembiraan politik milik publik, dan bukan hanya milik segelitir elite dan masyarakat politik belaka. Artinya dengan karakter saling berinteraksi dapat menjadi bentuk baru komunikasi rakyat dengan pemerintah serta pejabat terpilih sekaligus mendorong demokrasi partisipatoris. ${ }^{32}$

Hal ini membuat proses pelembagaan aktivisme digital dapat menjadi wahana pembelajaran pendidikan politik yang sekaligus menjadi bagian utuh dari perubahan kesadaran publik. Pembelajaran politik yang pada awalnya berkarakter satu arah menuju pembelajaran politik yang berwatak partisipatoris. Artinya, pola aktivisme digital dapat membuat peran para relawan politik lebih cepat dan mudah dalam memahami kondisi rakyatanya secara faktual maupun elementer sehingga informasi dapat menjadi sebuah deklarasi komitmen untuk melakukan hal-hal terbaik bagi publik. Disinilah titik nadir dari peran relawan di

\footnotetext{
32 Dalam hal ini demokrasi partisipatoris diartikan sebagai demokrasi yang melibatkan seluruh masyarakat dalam proses politik dan pengambilan keputusan publik, baik langsung maupun tidak langsung, dimana rakyat dapat mengajukan usul, masukan mengenai kebij akan yang akan ditetapkan oleh pemerintah. Lihat, Arianto, Bambang. (2014). Fenomena Relawan Politik Dalam Kontestasi Presidensial 2014. Jurnal Ilmu Sosial dan Ilmu Politik. Vol. 18 No. 2 Edisi November.
} 
media sosial yakni mampu berperan ganda baik dalam ranah intra dan ekstra-parlementer guna menyebarluaskan program-program pemerintahan Jokowi-JK.

Pelembagaan aktivisme digital sebagai wahana pendidikan politik dapat menjadi penggerak utama untuk menghasilkan opini, wacana dan kesadaran tentang kebijakan yang transformatif. Meski demikian, peran relawan politik kedepan tetap perlu mengedepankan sinergisitas (kerjasama) antar gerakan netizen di media sosial dengan gerakan di dunia nyata. Sebab, transformasi perubahan atas kebijakan publik dalam ranah politik digital tidak cukup hanya dengan melalui media sosial semata. Sehingga melalui sinergisitas ini dapat menciptakan komunikasi nonhierarkis yang dapat melibatkan semua simpul demokrasi baik rakyat, relawan politik maupun pemerintahan Jokowi-JK.

\section{Kesimpulan}

Geliat dari kerja teritorial para relawan politik pasca elektoral 2014 terutama di ranah politik digital menjadi salah satu ikon pelembagaan aktivisme digital sekaligus wahana pendidikan politik bagi publik. Ikon tersebut didasari dengan dinamika peran yang diterapkan oleh para relawan politik yang lebih banyak bergerak di ranah media sosial. Alhasil peran para relawan ini kemudian dapat memberikan beberapa manfaat bagi para netizen dan publik diantaranya; Pertama sebagai sarana transformasi pengetahuan politik. Pengetahuan ini mengacu pada bentuk konsep, informasi dan pertimbangan faktual, mengenai sistem pemerintahan dan politik. Kedua, merupakan keterampilan intelektual terkait kepiawaian dalam mengambarkan, menginterpretasikan dan menilai fenomena politik. Kepiawaian ini untuk membatasi terjadinya fanatisme yang berlebihan dari satu kesatuan politik. Ketiga, sebagai sarana untuk membangun partisipasi politik. Partisipasi ini dapat menjadi bekal para netizen untuk dapat memaksimalkan interaksi dengan jejaring lainnya baik secara personal maupun kelompok dalam menyusun keputusaan politik serta pemerintahan. Keempat, sebagai sarana untuk mempengaruhi sikap netizen, sehingga menjadi ruh dalam segala jenis tindakan guna membangun patriotisme dan nasionalisme. Dengan catatan beberapa manfaat tersebut harus dapat disandingkan dengan hakikat dan nilai-nilai kerelawanan (volunterisme) para relawan politik. Sebab, nilai-nilai tersebut dipercaya mengandung semangat revolusi mental, gotong royong serta dapat meminimalisir watak kekuasaan yang seringkali menjadi kultur politik Indonesia.

Harapan kedepan relawan politik baik intra maupun ekstra-parlementer bisa membangun sinergisitas kerja dan wacana. Sinergisitas ini dapat menjadi alternatif dalam upaya menawarkan wacana pemikiran alternatif bagi konsep kebijakan publik yang lebih memihak pada rakyat. Sehingga para relawan bisa konsisten menyediakan berbagai informasi yang berguna bagi publik dan netizen terutama seputar kebijakan pemerintahan. Informasi ini sejatinya dapat menjadi suplemen bagi pemberdayaan, pendidikan politik melalui jejaring media sosial. Akhirnya, melalui geliat para relawan dalam memperkuat pelembagaan aktivisme digital dapat dijadikan salah satu wujud alat kontrol bagi para relawan dan publik untuk mengawasi jalannya pemerintahan agar dapat bekerja sesuai semangat Nawacita dan revolusi mental. Apabila langkah ini dapat berjalan secara simultan, baik relawan politik yang berada dalam ranah intra dan ekstra parlementer bisa menciptakan diskursus bersama dari dinamika yang mencerminkan kehendak publik sebagai wujud proses pembelajaran politik publik.

\section{Daftar Pustaka}

Arianto, Bambang. (2014). Fenomena Relawan Politik Dalam Kontestasi Presidensial 2014. Jurnal Ilmu Sosial dan Ilmu Politik. Vol. 18, No. 2 Edisi November. 
(2015). Kampanye Kreatif dalam Kontestasi Presidensial 2014. Jurnal Ilmu Sosial dan Ilmu Politik. Vol. 19, No. 1 Edisi Juli.

(2016). Buzzer Politik dan Informasi Hoax. Harian Kedaulatan Rakyat. Edisi 28 November

Amnå, Erik and Ekman. Joakim. (2013). Standby citizens: diverse faces of political passivity. European Political Science Review. FirstView Article. June 2013, pp 121

Dewantara dkk. (2015). Aktivisme dan Kesukarelawanan dalam Media Sosial: Komunitas Kaum Muda Yogyakarta. Jurnal Ilmu Sosial dan Ilmu Politik. Vol. 19, No. 1 Edisi Juli

Demosindonesia.org. (2016). Hasil penelitian Lembaga Demos, Membaca Dinamika relawan Politik (2015). (Online) (http:// demosindonesia.org/2015/06/membacadinamika-relawan-jokowi, diakses 4 Desember 2015).

Don Tapscott. (2009). Grown Up Digital: How the Net Generation is Changing Your World. McGraw Hill Professional, 2008

Fikri AF, Akhmad (1999). Menjadi Politisi Ekstra Parlementer. Yogyakarta: Penerbit LKIS

Hamid, Veronica. (2014) Merancang Arah Baru Demokrasi, Indonesia Pasca Reformasi: Angin Harapan Demokrasi Digital, Nostalgia Demokrasi Klasik, Transformasi Ruang Publik dan Politisasi Media Sosial. Jakarta: Kepustakaan Populer Gramedia (KPG).

Haris, Syamsudin. 13 Agustus 2014. Kabinet Impian. Kompas.

Heryanto, Gun Gun. 4 April 2016. Partisipasi Politik Generasi Digital. Kompas.

Jati, WR (2015). Prospek Politik Digital dalam Kelas Menengah Indonesia. (Online). (http://www.politik.lipi.go.id/kolom-2/ politik-nasional/1012-wasisto-raharjo-jati. diakses 5 Mei 2016).

(2015). Cyberspace, Internet dan

Ruang Publik Baru: Aktivisme Online Politik kelas Menengah Indonesia. Jurnal
Pemikiran Sosiologi. (Online). (http://jps. fisipol.ugm.ac.id/index.php/jps/article/ view/34, diakses 10 januari 2016)

Jokopedia.org. (2016). Akun-akun media sosial Jokopedia. (Online). (http://jokopedia.org/ index.php?title=Halaman_Utama)

Kleden, Ignas. 15-21 Desember 2014. Kembalinya Voluntarisme dalam Politik. Majalah Tempo.

Kompas.com. (2016). Tidak.Ada.Makan. Siang.Gratis.bagi.Para.Relawan (Online). (http://megapolitan.kompas.com/ read/2016/03/31/09185951/.Tidak. Ada.Makan.Siang.Gratis.bagi.Para. Relawan.?utm_source=news\&utm $\mathrm{m}$ e d i u m $=\mathrm{b} \mathrm{p}-\mathrm{ko} \mathrm{m} \mathrm{pas} \mathrm{\&} \mathrm{u} \mathrm{t} \mathrm{m}$ campaign $=$ related $\&$, diakses 10 Januari 2016).

Kristiadi J. 12 Agustus 2014. Tim transisi dan Ancaman Politik Transaksi. Kompas.

Lukmantoro, Triyono. (2015). Komunikasi Politik di Era Digital. Jakarta: Universitas Multimedia Nusantara Press.

Nawacitanews.com. (2015). Forum Bagimu Negeri Dibentuk Sebagai Pengawal Nawacita di BUMN. (Online). (http://www. nawacitanews.com/forum-bagimu-negeridibentuk-sebagai-pengawal-nawacita-dibumn, diakses Januari 2016)

Nugroho, Y., \& Syarief, S. S. (2012). Serifesmedia Asia: Melampaui Aktivisme click? Media Baru dan Proses Politik dalam Indonesia Kontemporer. Jakarta: Friedriech-Ebert-Stiftung Kantor Perwakilan Indonesia.

Prast, Hari, dkk. (2014). Demokreatif, Kisah Blusukan Jokowi. Jakarta: Kepustakaan Populer Gramedia (KPG).

Priyono, AE. (2012). Facebook Indonesia: Morfologi Sosial dan Spektrum Politiknya. Public Virtue Indonesia. http://virtue.or.id/

Postill, J. (2012). Digital Politics and Political Engagement. in Horst and D.Miller (eds), Digital Anthropology, Berg, Oxford.

Rotman, D., Viewe, g. S., Yardi, S., Chi, E., Preece, J., Shneiderman, B., Glaisyer, T. (2011). From 
slacktivism to activism: participatory culture in the age of social media. Proceedings of the 2011 annual conference extended abstracts on Human factors in computing systems. New York, NY, USA: ACM.

Savirani, Amalinda. 9 Juni 2016. Publik Opinion: Between Haters and Lovers. The Jakarta Post. Somantri, Muhammad Numan. (2001). Menggagas Pembaharuan Pendidikan IPS. Bandung: Penerbit Remaja Rosdakarya.

Sugihartati, Rahma. 10 Februari 2016. Hater di Ruang Publik. Harian Jawa Pos.

Susilo, Djokowi. 19 Agustus 2015. Ketika Relawan Menjadi Dubes RI. Harian Jawa Pos.
Tempo.co. (2015). Pendukung Jokowi Bentuk Partai Indonesia Kerja. (Online). (http://m. tempo.co/read/news/2016/06/01/, diakses 1 Juni 2016)

\section{Wawancara}

Wawancara dengan Retnowidarti Wulandari relawan non-komunitas

Wawancara dengan Ginanjar Rahmawan Tartowiharjo, relawan JASMEV 2014

Wawancara dengan Dyah Kartika Rini Djoemadi Koordinator relawan JASMEV 2014

Wawancara dengan Iswandi $\mathrm{F}$ Tanjung Koordinator Wilayah JASMEV DKI Jakarta 